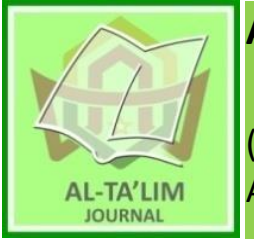

AL-TA'LIM JOURNAL, 28 (2), 2021, (125-133)

(Print ISSN 1410-7546 Online ISSN 2355-7893)

Available online at http://journal.tarbiyahiainib.ac.id/index.php/attalim

\title{
The Correlation between Lecturers' Performance in Supervising Thesis and Thesis Quality in IAIN Palu
}

Received: 23 $3^{\text {h }}$ February 2021; Revised: 31 ${ }^{\text {th }}$ July 2021; Accepted: $31^{\text {th }}$ July 2021

Permalink/DOI: http://dx.doi.org/10.15548/jt.v28i2.684

\section{Erniati *)}

Institut Agama Islam Palu, Sulawesi

Tengah, Indonesia.

E-mail: erniati@iainpalu.ac.id

\section{Khaeruddin Yusuf}

Institut Agama Islam Palu, Sulawesi

Tengah, Indonesia.

E-mail: khaeruddin@iainpalu.ac.id

\section{Andi Nurul Hidayat}

Universitas Tadulako Palu, Sulawesi

Tengah, Indonesia.

*) Corresponding Author

\begin{abstract}
This article aims to determine lecturers' performance in supervising thesis with thesis quality of students of Faculty of Islamic Education and Teacher Training IAIN Palu. This is a quantitative study investigating 285 students of Faculty of Islamic Education and Teacher Training IAIN Palu. who had finished their thesis examinations in 2020 by using proportional sampling technique? The data collection techniques were surveys, observation, interview and documentation. The results showed that the performance of the lecturers in supervising the thesis was in good category with an average (mean) score of 79.79 and the quality of the thesis was in the good category with the average score (mean) of 81.16. There is a significant correlation between the performance of the lecturer in supervising the thesis and the thesis quality of the students.
\end{abstract}

Keywords: Thesis quality; lecturers' performance; supervising thesis.

How to Cite: Erniati, E., Yusuf, K., \& Hidayat, A. (2021). The Correlation between Lecturers' Performance in Supervising Thesis and Thesis Quality in IAIN Palu. Al-Ta lim Journal, 28(2), 125-133. doi:https://doi.org/10.15548/jt.v28i2.684

\section{INTRODUCTION}

Higher education determines one of the standards for student graduation to obtain a bachelor's degree (undergraduate/S1) in the form drafting a final project or thesis (Drennan \& Clarke, 2009; Hamilton et al., 2010; Tuononen \& Parpala, 2021). The purpose of this thesis is to train students to carry out research correctly in the field of science they are engaged in, guided by an supervisor (Asmawi, 2010; Firdausi et al., 2020). Thesis writing is an obligation for every student which can be started from the 7th (seventh) semester if it meets the specified requirements (Honan \& Bright, 2016; Li \&
Vandermensbrugghe, 2011; Wang \& Li, 2008).

The quality of the thesis written by students has received great attention from universities (Aghaee \& Hansson, 2013; Golding et al., 2014; Reynolds \& Thompson $\mathrm{Jr}, 2011)$. Because it concerns with the quality of graduates in the field of scientific writing, including the State Institute for Islamic Studies (IAIN) Palu. Therefore, the top management of IAIN Palu continues to strive to improve the quality of the thesis by improving services to students in thesis writing activities by providing supervisors who are experts in their fields who have an openness attitude and have self-awareness. 
However, in the supervision process, sometimes both lecturers and students experience many obstacles, including students having difficulties in meeting their supervisors because of the situation during the Pandemic of Covid-19, long queues of other students who want to consult to the same supervisor, or supervisors who are busy with the project they are handling because the project has approached deadline. In addition, sometimes students do not have the commitment or disciplinary to quickly complete their thesis, for example students rarely do consultations but when the deadline for thesis collection is approaching, students rush to ask for guidance so that the results obtained are not optimal and such situations, supervisors are considered unhelpful by the students, and this often happens at IAIN Palu.

Based on the above phenomenon, the researcher is interested in conducting research on the correlation between lecturers' performance in supervising the thesis and the thesis quality of students of Faculty of Islamic Education and Teacher Training IAIN Palu. Because the problem of the thesis supervisor and the quality of the thesis and the commitment of students in preparing the thesis is a complicated problem that needs to be solved as soon as possible. This research hoped to obtain a solution to improve the performance of lecturers in supervising and improving the quality of the thesis written by students at IAIN Palu.

The research study that is relevant to this research is the research conducted by Rini Maryuni Hariyati titled Survey of lecturer performance in supervising the thesis and thesis quality of STIE Malangkucecwara students. The study aimed to find out the performance of the thesis supervisors and the thesis quality of STIE Malangkucecwara students. The study used a survey method. The variables in the research were performance measurement, openness attitude of the supervisor, self-awareness of the supervisor, student satisfaction and the quality of the thesis (Hariyati, 2012).

The difference between Rini Maryuni Hariyati's research and the research conducted by researcher now lies in its objectives. In this research, researchers conducted not only to describe the performance of lecturers in guiding the thesis and the quality of the thesis produced by students, but this research will also explain the correlation between the two variables, namely the performance of the lecturer in supervising the thesis and the quality of the thesis of Faculty of Islamic Education and Teacher Training IAIN Palu.

\section{METHOD}

The approach used in this study is the quantitative approach, and the population in this study were students of Faculty of Islamic Education and Teacher Training IAIN Palu who had finished their thesis examinations in 2020 as many as 285 students. The sampling technique used was the proportional sampling technique using a formula developed by Slovin with a significance level of $95 \%$ (0.05), and an error of $90 \%$ (0.10). For a population of 285 , the sample is 74 students. The data collection techniques used weresurvey, observation, interviewand documentation of the thesis scores. The data analysis technique used is descriptive analysis techniques and statistical analysis techniques of correlation and regression to analyze how far is the correlation between lecturers' performance with the students' theses quality. (Kartono 2017; Jonathan 2019; Kartono 2017; Arikunto 2016; Creswell 2018).

\section{RESULT AND DISCUSSION}

\section{Lecturers' performance in thesis Supervision}

Lecturers are professional educators and scientists whose main task is to supervise thesis. Assessment of lecturer performance in supervising thesis can be seen in two indicators, namely: openness attitude and selfawareness of the supervisor which are described as follows:

\section{Openness Attitude of Supervisors}

Based on the results of research conducted by researchers on 74 students regarding the performance based on the 
indicator of the openness attitude of the lecturers, the following data were obtained:

\section{Table 1. Openness Attitude of Lecturers during Thesis Supervision}

\begin{tabular}{lrr}
\hline $\mathrm{N}$ & Valid & 74 \\
& Missing & 0 \\
Mean & & 80.2787 \\
Median & & 81.2500 \\
Mode & & 81.25 \\
Std. Deviation & & 1.12486 \\
Minimum & & 56.25 \\
Maximum & & 100.00 \\
\hline
\end{tabular}

Based on the table above, it is very clear that the lecturers' performance in thesis supervising, especially on the indicator of the openness attitude of the lecturers in supervising thesis was in the good category. It can be seen in the average value obtained on this indicator of 80.27. However, when viewed from the maximum and minimum scores, the range were very far. The maximum value obtained by the lecturer when viewed from this aspect is 100 and the minimum is 56.25 . To find out the frequency distribution of the lecturers' performance in thesis supervising on the indicator of lecturer's openness attitude, it can be seen in the following table:

Table 2. Frequency Distribution on Openness Attitude of Supervisors

\begin{tabular}{ccccc}
\hline No & $\begin{array}{c}\text { Percentage of } \\
\text { achievement }\end{array}$ & Frequency & $\%$ & Category \\
1 & $100-85$ & 30 & $40,5 \%$ & Very \\
& & & & Good \\
2 & $84-75$ & 22 & $29,7 \%$ & Good \\
3 & $74-65$ & 15 & $20,3 \%$ & Average \\
4 & $64-0$ & 7 & $9,5 \%$ & Poor \\
& Total & 74 & $100 \%$ & \\
\hline
\end{tabular}

Based on the table above, it appears that of the 74 lecturers of Faculty of Islamic Education and Teacher Training IAIN Palu, there were 30 or $40.5 \%$ of the lecturers who had an openness attitude in supervising thesis in Very Good category, 22 or $29,7 \%$ lecturers who had an openness attitude in supervising thesis in Good category, and 15 or $20,7 \%$ lecturers who had an openness attitude in supervising thesis in Average category, and also 7 or $9,5 \%$ lecturers who had an openness attitude in supervising thesis in Poor category. This research was also supported by the results of interviews with students (Fikri, 2020) who stated that there were some lecturers who did not show an openness attitude such as not directing students to access electronic journals and printed scientific information, and did not provide reexplanation of the corrections/revisions given tabel.

According to Adhimiharja, a lecturer should have an open attitude/ communication which is measured through several preparations. The first preparation is preparing things related to the title material that has been agreed between the supervisor and the student after going through the proposal examination process. Next is preparing reading materials for students, providing theoretical understanding of chapters in a thesis, explaining theoretically the thesis arrangement in accordance with the campus writing rules and guides and explaining in detail chapter by chapter, learning the contents and titles according to the writing technique and the extent to which students can understand the message conveyed by the supervisor. (for example, spaces, periods, commas, and so on). The lecturer directs students to write a proposal /thesis according to the applicable guidelines (Adhimihardja, 2005).

Interpersonal communication has a very big influence in working on and drafting the thesis, the relationship between students and supervisors must be managed properly and students need to understand what the supervisor expects of.

\section{Self-awareness of the Supervisors}

Self-awareness of the supervisors was measured by the time indicator provided by the lecturer for proposal/thesis consultation, the supervisor is willing to accept students outside the agreed supervision schedule, and the time frame provided by the lecturer to check the proposal and thesis (M Hasan, tth; Hariyati, 2012b). This research found that most lecturers are aware of their roles and responsibilities 
Table 3. Self-awareness of the Supervisors

\begin{tabular}{|c|c|c|}
\hline \multicolumn{3}{|c|}{ Statistics } \\
\hline $\mathrm{N}$ & Valid & 74 \\
\hline & Missing & 0 \\
\hline \multicolumn{2}{|c|}{ Mean } & 79.25 \\
\hline \multicolumn{2}{|c|}{ Median } & 78.57 \\
\hline \multicolumn{2}{|c|}{ Mode } & 75.00 \\
\hline \multicolumn{2}{|c|}{ Std. Deviation } & 8.84 \\
\hline \multicolumn{2}{|c|}{ Minimum } & 60.71 \\
\hline \multicolumn{2}{|c|}{ Maximum } & 92.86 \\
\hline
\end{tabular}

The data shows that the performance of the lecturer in thesis supervising, especially in the indicators of self-awareness of the supervisor, is in the good category, this can be seen from the average value (mean) of this indicator is 79.25 . The maximum value is 92.86 and the minimum value is 60.71 with a standard deviation of 8.84 . To find out the frequency distribution of the lecturer performance in supervising thesis on the indicator of self-awareness of the supervisor, it can be seen in the table as follows:

Table 4. Frequency Distribution on Self-awareness

\begin{tabular}{ccccc}
\multicolumn{5}{c}{ of the Supervisor } \\
\hline No & $\begin{array}{c}\text { Percentage } \\
\text { of } \\
\text { achievement } \\
1\end{array}$ & Frequency & $\%$ & Category \\
& $100-85$ & 29 & 39.2 & Very \\
2 & $84-75$ & 32 & 43.2 & Good \\
3 & $74-65$ & 3 & $4,1 \%$ & Average \\
4 & $64-0$ & 10 & 13.5 & Poor \\
& & & $\%$ & \\
& Total & 74 & $100 \%$ & \\
\hline
\end{tabular}

Based on the table above, it showed the frequency of 74 Faculty of Islamic Education and Teacher Training IAIN Palu. lecturers who were the research sample. There were 29 or $39.2 \%$ of the lecturers who had Very Good self-awareness in thesis supervising, 32 or $43.2 \%$ of the lecturers who had self-awareness in supervising the thesis was in Good Category and 3 or $4.1 \%$ of the lecturers who had self-awareness in supervising the thesis was in Average Category, also 10 or 13,5 of the lecturers who had self-awareness in supervising the thesis was in Poor Category. This research was also supported by the results of interviews with students who stated that there were some lecturers who did not show self-awareness such as being difficult to find and unwilling to be met outside of the predetermined schedule.

From the results of the data description on each of the above indicators, it can be concluded that the overall average (mean) performance of the lecturers in thesis supervising is 79.79 , which means good with a standard deviation of 8.48 , a maximum value of 91.7 and a minimum value of 61.7.

The data above is in line with what the supervisor should do. Collaboration between the supervisor and the student is very important for the success of thesis guidance. Therefore, the mentor's ability to create good communication is a skill that a mentor needs to have. In other words, the mentor must be able to act as a good communicator (Siswohardjono, 2018).

\section{Description of Thesis Quality of Students of Faculty of Islamic Education and Teacher Training IAIN Palu}

Thesis is a final project in the form of a scientific paper written by undergraduate students at the end of their studies based on the results of research or literature review, or the development of a problem that has been carried out carefully. The purpose of thesis is to train students to carry out research correctly in their respective fields of knowledge, guided by a supervisor (Penyusun, 2012). Thesis writing is an obligation for every student, it can be started from semester 7 (seven) if it meets the specified requirements. The quality of a student's thesis can be assessed from the suitability of the thesis using scientific methods and procedures, which include problems, theory studies, hypotheses, population and sampling techniques, testing the validity and reliability of instruments, research methods, data analysis techniques, conclusions and recommendations (Winkel, 2017; Zirmansyah, 2011).

The results of the research carried out using documentation, questionnaire and field 
observations on 74 students works/theses, the following data was obtained:

\begin{tabular}{lcc}
\multicolumn{3}{c}{ Table 5. Quality of the Thesis } \\
\hline \multicolumn{1}{c}{ N } & Valid & 74 \\
& Missing & 0 \\
Mean & 81.16 \\
Median & 82.00 \\
Mode & 82.00 \\
Std. Deviation & 6.195 \\
Minimum & 65.00 \\
Maximum & 97.00 \\
\hline
\end{tabular}

Based on the table above, the mean value of the thesis quality of 74 students is 81.16 which means Good, with the most frequent score (mode) is 82 with a standard deviation of 6.195 and the maximum value obtained by students is 97 and the minimum score obtained by students of 65 . From the description above, it is clear that the quality of the student thesis of Faculty of Islamic Education and Teacher Training IAIN Palu was in Good category. However, there are some students whose thesis is in Poor category. This can be explained by the frequency distribution of the thesis quality as follows:

Table 6. Frequency Distribution of Thesis Quality

\begin{tabular}{|c|c|c|c|c|}
\hline $\mathrm{N}$ & Percentage & Frequenc & Percentag & Categor \\
\hline o & $\begin{array}{c}\text { of } \\
\text { achievemen } \\
\mathrm{t}\end{array}$ & $\mathrm{y}$ & $\mathrm{e}$ & $\mathrm{y}$ \\
\hline 1 & $100-85$ & 19 & $25.68 \%$ & $\begin{array}{l}\text { Very } \\
\text { Good }\end{array}$ \\
\hline 2 & $84-75$ & 49 & $66.22 \%$ & Good \\
\hline 3 & $74-65$ & 6 & $8 \%$ & Average \\
\hline 4 & $64-0$ & 0 & $0 \%$ & Poor \\
\hline & Total & 74 & $100 \%$ & \\
\hline
\end{tabular}

Based on the data above, of the 74 students whose thesis quality were scored, there were 19 or $25.68 \%$ students whose thesis quality was Very Good. It can be proven that there are 2 students whose thesis writing uses foreign languages, namely English and Arabic and there are those who make new breakthroughs in their research so they deserve to get the best score. Meanwhile, there were 49 or $66.22 \%$ of students whose thesis quality was in the Good category and there were 6 or $8 \%$ whose thesis quality was in Average category. Especially for students whose thesis quality is insufficient/ sufficient, the error lies in the language grammar of the writing and the references used, the methodology used is inaccurate and sometimes they do not master the content of the thesis so that the content cannot be accounted for. There are even some students who do not work on their own thesis or the thesis was written by someone else.

Therefore, to reduce the quality of the thesis which is considered less than optimal, the supervisor should maximize their main function as a supervisor by following the steps such as: Discuss with the students about problems that are the object of student attention, discuss the time of guidance, places of guidance, how to guide whether in whole or by chapter, check accurately and thoroughly between the problem, goal, hypothesis, treatment design or selected variables, data analysis and conclusions, writing format etc (Adhimihardja, 2005; M Hasan, tth; Pratama, 2017).

\section{The Correlation between Lecturers' Performance in Supervising Thesis and Thesis Quality}

Before testing the hypothesis of the correlation between lecturers' performance in supervising thesis and the quality of the thesis of Faculty of Islamic Education and Teacher Training IAIN Palu, the data analysis requirements were tested first. The test of the requirements analysis was the normality test. Normality test is used as a requirement of analysis using parametric statistics. In addition, the normality test is also used to determine whether the sample studied is normally distributed or not.

The normality test was carried out using the Kolmogorov-Smirnova normality test with the help of SPSS For Windows 16. The significance level is set at 0.05 , provided that the significance of the normality test 
results is more than 0.05 , it means the data is normal, whereas if the significance of the normality test results is less than 0.05 , the data is not normal. Based on the results of the analysis of the normality test, the following data were obtained:

Table 7. Data of Normality Test

\begin{tabular}{|c|c|c|c|c|}
\hline \multirow[t]{2}{*}{ Variabel } & \multicolumn{3}{|c|}{ Kolmogorov-Smirnova } & Results \\
\hline & Statistic & Df & Sig & Sig $>0,05$ \\
\hline $\begin{array}{l}\text { Lecturer } \\
\text { performance } \\
\text { in thesis } \\
\text { supervising }\end{array}$ & 1.460 & 74 & 8 & Normal \\
\hline $\begin{array}{l}\text { Thesis } \\
\text { Quality }\end{array}$ & 1.073 & 74 & 0 & Normal \\
\hline
\end{tabular}

Test distribution is Normal

Based on the table above, it can be explained that the significance of the lecturer performance variable in thesis supervising is 0.058 , which means that it is greater than 0.05 , this means that the data is normally distributed. Meanwhile, the significance of the thesis quality variable is 0.200 , which means that it is greater 0.05 which means that the data is normally distributed. Based on the results of the normality test above, the analysis can be continued using parametric statistics.

The statistical analysis used to test the correlation coefficient/correlation between lecturer performance in thesis supervising with the thesis quality of Tarbiyah students and Teacher Training at IAIN Palu was carried out by using Pearson's product moment analysis. With the test criteria: if $\mathrm{r}$ count $>r$ table: Ho is rejected and if $r$ count $<r$ table: Ho is accepted. Based on the results of research and data analysis, the following data were obtained:
Table 8. Correlation analysis of the Performance of the Lecturer in Thesis Supervising with the Thesis

Quality of the Faculty of Islamic Education and Teacher Training IAIN Palu

Correlations

\begin{tabular}{|c|c|c|c|}
\hline & & $\begin{array}{c}\text { Thesis } \\
\text { Quality } \\
\text { (y) }\end{array}$ & $\begin{array}{l}\text { Lecturers' } \\
\text { Performanc } \\
\text { e (x) }\end{array}$ \\
\hline \multirow[t]{2}{*}{$\begin{array}{l}\text { Pearson } \\
\text { Correlation }\end{array}$} & Thesis Quality (y) & 1,000 & 0,804 \\
\hline & $\begin{array}{l}\text { Lecturers' } \\
\text { Performance (x) }\end{array}$ & 0,804 & 1,000 \\
\hline \multirow{2}{*}{$\begin{array}{l}\text { Sig. (1- } \\
\text { tailed) }\end{array}$} & Thesis Quality (y) & . & 0,000 \\
\hline & $\begin{array}{l}\text { Lecturers' } \\
\text { Performance (x) }\end{array}$ & 0,000 & . \\
\hline \multirow[t]{2}{*}{$\mathrm{N}$} & Thesis Quality (y) & 74 & 74 \\
\hline & $\begin{array}{l}\text { Lecturers' } \\
\text { Performance (x) }\end{array}$ & 74 & 74 \\
\hline
\end{tabular}

Based on the table above, the correlation index price (rxy) is 0.804 . The price of $\mathrm{r}$ table Product Moment table is 0.227 with $\mathrm{N}=74$ and the significance level is set at $5 \%$. Thus, if $r$ count $=0,804>r$ table $=0,227$ this means that $\mathrm{Ho}$ is rejected and $\mathrm{Ha}$ is accepted. This shows that there is a very strong correlation between the performance of the lecturer in supervising the thesis and the thesis quality of the students of Faculty of Islamic Education and Teacher Training IAIN Palu. While the significance level of the correlation coefficient is 0.000 . Because the probability is far below 0.05 , the correlation between the performance of the lecturer in thesis supervising and the quality of the thesis written by students of Faculty of Islamic Education and Teacher Training IAIN Palu was significant. This research is supported by the results of research conducted by (Adek, 2014; Amalia, 2018; Damanhuri et al., 2016; Sari, 2018) which states that there is a significant correlation between the performance of the lecturer in thesis supervising and the quality of the student thesis.

Meanwhile, the contribution of the lecturer performance variable in supervising 
the thesis to the quality of the thesis written by students is $=\mathrm{r}^{2} \times 100 \%=0.804^{2} \times 100 \%$ $=64.64 \%$, this means that the contribution of lecturer performance in supervising thesis is $64.64 \%$ and the remaining $35.36 \%$ is determined by other variables. Other variables according to Siswohardjono, include factors such as IQ (intellectual intelligence), EQ (emotional intelligence), health, motivation, resilience, interests and others (Siswohardjono, 2018).

Based on the results of the analysis, the regression equation between motivation and lecturers' performance variables is as follows:

Table 9. Regression Equation

\begin{tabular}{|c|c|c|c|c|c|}
\hline \multicolumn{6}{|c|}{ Coefficients $^{\mathbf{a}}$} \\
\hline & $\begin{array}{l}\text { Unstandardized } \\
\text { Coefficients }\end{array}$ & $\begin{array}{l}\text { Standardized } \\
\text { Coefficients }\end{array}$ & $\mathrm{t}$ & \multicolumn{2}{|c|}{ Sig. } \\
\hline Model & B & Std. Error & Beta & & \\
\hline (Constant) & 34,311 & 4,103 & & 8,362 & 0,000 \\
\hline $\begin{array}{c}\text { Lecturers' } \\
\text { Performanc } \\
\text { e }\end{array}$ & 0,587 & 0,051 & 0,804 & 11,482 & 0,000 \\
\hline a. Depen & ent Variable: THF & S QUALITY & & & \\
\hline
\end{tabular}

Based on the table above, the regression equation of lecturer performance in thesis supervising $(\mathrm{X})$ and the quality of the thesis of Faculty of Islamic Education and Teacher Training IAIN Palu (Y) with constants $(\mathrm{a}=$ thesis quality $)=34,311$ and $(\mathrm{b}$ $=$ lecturer performance in supervising thesis) $=0.587$ was as follows $\mathrm{y}=\mathrm{a}+\mathrm{bx}=34.311+$ $0.587 \mathrm{X}$. This shows that if the performance of the lecturer in thesis supervising increases by one unit, the quality of the student thesis will also increase by one unit. This means that if the performance of the lecturer in thesis supervising increases, the quality of the thesis will increase. This is relevant to the opinion of (Firdausi et al., 2020; Harisantoso, 2012; Yusuf et al., 2019) which states that one of the factors that determine the success of thesis guidance is the supervisor themselves. This includes the mentor's personality, physical health, mastery of the material on the problem studied, study background and experience of the supervisor, and the supervisor's ability to build communication.

Furthermore, to test the significance of the constants and variable of lecturers' performance in thesis supervising, it was carried out using the $t$ test. Based on the table, it is obtained that $t$ count on the variable of lecturer performance in thesis supervising is 11.483 and $\mathrm{t}$ table with $\mathrm{dk}$ of $74-2=72$ for one-sided test is 1.662. Because $t$ count (11.482)> $\mathrm{t}$ table value (1.662), Ho is rejected, meaning that the regression coefficient is significant or the performance of the lecturer in the thesis supervising actually has a significant correaltion with the quality of the thesis of students of Faculty of Islamic Education and Teacher Training IAIN Palu.

\section{CONCLUSION AND RECOMMENDATION}

The performance of the lecturers at Faculty of Islamic Education and Teacher Training IAIN Palu in the thesis supervision was in the Good category with the average (mean) of 79.79. The quality of the student thesis of Faculty of Islamic Education and Teacher Training IAIN Palu is in the Good category with the average value (mean) of 81.16. 
There is a significant correlation between the performance of the lecturer in thesis supervising and the thesis quality of the students of the Faculty of Tarbiyah and Teacher Training with a correlation index (rxy) of 0.804 with a significance level of $5 \%$. The contribution of the lecturer performance variable in thesis supervising to the quality of the thesis written by students is $=r^{2} \times 100 \%$ $=0.8042 \times 100 \%=64.64 \%$, this means that the contribution of lecturer performance in supervising thesis is only $64.64 \%$ and the rest is $35,36 \%$ determined by other variables including factors of IQ (intellectual intelligence), EQ (emotional intelligence) health, motivation, tenacity, interests and others.

Based on the results of this study, it is suggested that the officials in Faculty of Islamic Education and Teacher Training IAIN Palu make improvements in the thesis guidance process, namely: First, improve the quality of the thesis they supervise. Second, the quality of student preparation in facing the thesis examination. Third, students' timeliness in completing their thesis.

\section{REFERENCES}

Adek, R. (2014). Analisis Hubungan Kinerja Dosen Pembimbing Skripsi Dan Kualitas Skripsi Mahasiswa Akuntansi Pada Universitas Pembangunan Nasional "Veteran" Jawa Timur [PhD Thesis]. UPN" Veteran" Jawa Timur.

Adhimihardja, M. (2005). Bimbingan Belajar dan Bimbingan Skripsi [Working Paper]. Lokakarya Peningkatan Mutu Pembelajaran di Perguruan Tinggi, Kerjasama Higher Education Development Support dan Universitas Lampung.

Aghaee, N., \& Hansson, H. (2013). Peer Portal: Quality enhancement in thesis writing using self-managed peer review on a mass scale. International Review of Research in Open and Distributed Learning, 14(1), 186-203.

Amalia, R. R. (2018). Gambaran Persepsi Mahasiswa Semester Akhir Tentang
Peran Dan Kualitas Bimbingan Dosen Pembimbing Skripsi [PhD Thesis]. University of Muhammadiyah Malang.

Arikunto, S. (2016). Prosedur Penelitian Suatu Pendekatan Praktek (XIII). Rineka Cipta.

Asmawi, M. R. (2010). Strategi meningkatkan lulusan bermutu di perguruan tinggi. Hubs-Asia, 10(1).

Creswell, J. W. (2018). Research Design. Pustaka Belajar.

Damanhuri, D., Nulhakim, L., \& Mukhtar, M. (2016). Hubungan Self-Efficacy Dosen Dengan Self-Efficacy Mahasiswa Yang Sedang Menyusun Skripsi Di Semester Ganjil 2015/2016 Universitas Sultan Ageng Tirtayasa. JPsd (Jurnal Pendidikan Sekolah Dasar), 2(1), 39-49.

Darmono, \& M Hasan, A. (tth). Menyelesaikan Skripsi Dalam Satu Semester. Grasindo Gie The Liang.

Drennan, J., \& Clarke, M. (2009). Coursework master's programmes: The student's experience of research and research supervision. Studies in Higher Education, 34(5), 483-500.

Firdausi, H., Diana, N., \& Junaidi, J. (2020). Pengaruh Kinerja Dosen Pembimbing Skripsi Terhadap Kualitas Skripsi Mahasiswa (Studi Kasus Pada Mahasiswa S1 Akuntansi FEB UNISMA). Jurnal Ilmiah Riset Akuntansi, 9(11).

Golding, C., Sharmini, S., \& Lazarovitch, A. (2014). What examiners do: What thesis students should know. Assessment \& Evaluation in Higher Education, 39(5), 563-576.

Hamilton, P., Johnson, R., \& Poudrier, C. (2010). Measuring educational quality by appraising theses and dissertations: Pitfalls and remedies. Teaching in Higher Education, 15(5), 567-577. 
Harisantoso, J. (2012). Pengukuran Kinerja Dosen melalui EKD (Evaluasi Kinerja Dosen) STKIP PGRI Situbondo Berdasarkan Persepsi Mahasiswa. Sainteks, 9(2).

Hariyati, R. M. (2012a). Survey kinerja dosen pembimbing skripsi dan kualitas skripsi mahasiswa akuntansi stie malangkucecwara. Jurnal Dinamika Akuntansi, 4(2).

---. (2012b). Survey Kinerja Dosen Pembimbing Skripsi Dan Kualitas Skripsi Mahasiswa Akuntansi Stie Malangkucecwara. Jurnal Dinamika Akuntansi, $\quad 4(2)$. https://doi.org/10.15294/jda.v4i2.2170

Honan, E., \& Bright, D. (2016). Writing a thesis differently. International Journal of Qualitative Studies in Education, 29(5), 731-743.

Jonathan, C. (2019). Oxford Advanced Learner's Dictionary. Oxford University Press.

Kartono, K. (2017). Pengantar Metodologi Riset Sosial. Mandar Maju.

Li, L. Y., \& Vandermensbrugghe, J. (2011). Supporting the thesis writing process of international research students through an ongoing writing group. Innovations in Education and Teaching International, 48(2), 195205.

Penyusun, T. (2012). Panduan Penulisan Skripsi. Purwokerto: STAIN Press.

Pratama, R. A. (2017). Kualitas Komunikasi Interpersonal Dosen dan Motivasi Mahasiswa dalam Menulis Skripsi. Inter Komunika, 2(2), 114-122.

Reynolds, J. A., \& Thompson Jr, R. J. (2011). Want to improve undergraduate thesis writing? Engage students and their faculty readers in scientific peer review. $\mathrm{CBE}$-Life Sciences Education, 10(2), 209-215.
Sari, N. N. (2018). Hubungan Antara Persepsi Kinerja Dosen Pembimbing Skripsi Dengan Tingkat Motivasi Penyelesaian Skripsi Mahasiswa Angkatan $2012 \quad$ Universitas Muhammadiyah Gresik [PhD Thesis]. Universitas Muhammadiyah Gresik.

Siswohardjono, A. (2018). Perspektif Bimbingan Konseling dan Penerapannya di Berbagai Institusi. Satya Wacana.

Sugiono. (2018). Statistika untuk Penelitian (xvi ed.). Alfabeta.

Tuononen, T., \& Parpala, A. (2021). The role of academic competences and learning processes in predicting Bachelor's and Master's thesis grades. Studies in Educational Evaluation, 70, 101001.

Wang, T., \& Li, L. Y. (2008). Understanding international postgraduate research students' challenges and pedagogical needs in thesis writing. International Journal of Pedagogies and Learning, 4(3), 88-96.

Winkel, W. S. (2017). Bimbingan dan Konseling di Institusi Pendidikan. Grasindo.

Yusuf, M. Y., Hasnita, N., Dianah, A., \& Amri, A. (2019). Peranan Dosen Pembimbing Dalam Penyelesaian Laporan Kerja Praktikpada Fakultas Ekonomi Dan Bisnis Islam Uin ArRaniry. J-Iscan: Journal of Islamic Accounting Research, 1(1), 83-102.

Zirmansyah, Z. (2011). Kualitas Skripsi Mahasiswa Universitas Al Azhar Indonesia: Pengaruh Hasil Belajar Metodologi Penelitian dan Statistik terhadap Kualitas Skripsi. Jurnal AlAzhar Indonesia Seri Humaniora, 1(1), 19-28. https://doi.org/10.36722/sh.v1i1.20 